\title{
Identifying Motives of Japanese Investment in Indonesia from 2010 to 2016: A Preliminary Study
}

\author{
Rima Novita Sari ${ }^{1}$ and Asra Virgianita ${ }^{2}$ \\ \{1 rimanovita87@gmail.com, 2asrahiui@ui.ac.id\} \\ ${ }^{1}$ School of Strategic and Global, Universitas Indonesia, Indonesia \\ ${ }^{2}$ School of Strategic and Global Studies and Faculty of Social \& Political Sciences, \\ Universitas Indonesia, Indonesia
}

\begin{abstract}
Investment helps developing countries such as Indonesia meet their developing infrastructure goals, which are a priority of the Indonesian government. Japan, which has been a major investor in Indonesia since the 1970s, needs Indonesia as a provider of raw resources and also as an industrial base. Japanese multinational companies' investments in Asia have been successful. This study focuses on Japan's dynamic investment in Indonesia, from 2010 to 2016. The study employs a qualitative research and using John. H. Dunning's concept of OLI theory (ownership advantage, location advantage, and internalization advantage) to analyse the dynamics of Japanese investment in Indonesia. This study finds that motives of Japanese investment in Indonesia after 2010 were still focused on expanding market reach and having access to greater resources of Indonesia. The large base of manpower and a rising middle class are two facts that become main considerations of the Japanese investor's in Indonesia.
\end{abstract}

Keywords: Japan's Investment in Indonesia, Company Investment, OLI Theory

\section{INTRODUCTION}

A country's economic development is influenced by both internal and external factors, such as domestic economic conditions and bilateral cooperation between countries. Domestic conditions, such as the poverty rate, greater personal consumption, and declining inflation are indications that the government is maintaining the economy. An important external factor that affects a country's economy is foreign investment. Both Domestic Investments (Penanaman Modal Dalam Negeri or PMDN) and Foreign Direct Investments (Penanaman Modal Asing or PMA) create new job opportunities, transfer the latest technology from developed countries to developing countries, and stimulate the financial infrastructure.

Current economic globalization and Foreign Direct Investments (FDI) help developing countries access markets and technologies. Foreign multinational companies provide market access by establishing subsidiaries in other countries. Thus, a developing country, acting as a host country, can improve its competitive position, and the subsidiary can add to the parent company's profitability. FDIs in Indonesia give investors access to a new market, and the host country is opened up to greater international market competition. 
Foreign investments must consider a country's location and security. Indonesia's economy, which currently enjoys an export surplus, is predicted to grow by $5.4 \%$ in 2018 , and FDI also is expected to rise. After Singapore, Japan now is the second-largest foreign investor in Indonesia. Until 1998, Indonesia received more Japanese FDI than any other Southeast Asian country. In 1998, Japan's investment in Indonesia amounted to USD 11.543 million, followed by Thailand's USD 5.718 million. Japan's investment in Indonesia shrunk to USD 4.426 million in 1999, because many developed countries claimed that Indonesia's government failed to handle the Asian crisis. However, after ten years of fluctuating Japanese investment to Indonesia between 1999 and 2009, it rose during the 2010-16 period.

Table 1. Japan's Investment to Indonesia from 2010 to 2016

\begin{tabular}{|c|c|}
\hline Years & Investment Value (US\$ million) \\
\hline 2010 & $11.946,5$ \\
\hline 2011 & $15.816,3$ \\
\hline 2012 & $18.427,0$ \\
\hline 2013 & $19.787,2$ \\
\hline 2014 & $23.770,5$ \\
\hline 2015 & $24.531,6$ \\
\hline 2016 & $26.774,8$ \\
\hline
\end{tabular}

Source: Japan External Trade Organization (JETRO)

Based on table, the dynamics of Japan's investment in 2010 to 2016 are as follows:

1. The dynamics of Japan's investment to Indonesia in 2010 to 2016 has increased

2. Investment as a strategy or pattern of economic diplomacy Japan to Indonesia shows that Japan hasan economic interests in Indonesia

3. Up to now, investment is still centered on development in Java

Many studies about Japan's investments question whether they are advantageous or disadvantageous to the host country. Based on this questions, this study analysis Japanese investments to Indonesia from 2010 to 2016.

\section{METHODOLOGY}

This paper uses a qualitative research method, along with primary data from related institutes, such as Indonesia's Investment Coordinating Board (Badan Koordinasi Penanaman Modal Indonesia or BKPM) and the Japan External Trade Organization (JETRO). News sources were used to track current, global economic events. Irawan (2006, p. 24-25) envisioned the qualitative research method as a two-sided funnel with one side narrowed. This method is said to be same as inductive method, which depart from researcher general issues and open questioner from research object.

\section{LITERATURE REVIEW}

Using secondary data from the Central Bureau of Statistics Indonesia, Siwage and Latif discussed how foreign investment affected the productivity of local Indonesian industries between 1995 and 2005. Do foreign investments bring benefits or losses to a recipient country? 
Some advantages are technological transfers from developed countries to developing countries and additional job opportunities. Siwage and Latif opined that FDIs in Indonesia largely benefited the investor country. They found that Indonesia's FDI policies, until 2012, were not strategic and did not stimulate local industry growth. Today, foreign investment in Indonesia continues to grow, but local industries are unable to compete with foreign multinational corporations.

Investment is a form of bilateral cooperation between two trading countries. Dunning stated the reason for a country to consider the investment location, and Sita conducted research on Japan's fluctuating investment in Indonesia between 2001 and 2007, which can be explained by Indonesia's comparative advantage in natural and human resources and political and monetary country risk. Sita suggested that Japan's investment in Indonesia modernized its international trade. (Indonesia's trading gains, though, were halted by the Asian crisis, which affected the country's economic, political, and social conditions, causing it to lag behind other Southeast Asian countries).

In 2006, further research on Japanese investment was done by Muhammad Ramli, the Minister of the Economy during President Susilo Bambang Yudhono's tenure. Somewhat different from previous research that focused on Japan's investment in Indonesia, Ramli's research discussed how Indonesia's income tax incentives (PPH) affected foreign direct investment from Japan. He showed that Japanese foreign direct investment in Indonesia also takes into account tax incentives, which significantly improves the investment climate. This was an important incentive after Indonesia lost investments because of the Asian crisis. The tax incentives helped Japanese investors trust Indonesia. While FDI was expected provide technological transfers, Indonesia's local industry generally is less competitive than the subsidiaries of foreign multinationals. Security and domestic tax policies will continue to stimulate Japan's investments in Indonesia.

Based on the existing literature, this study found that most of study focused on the motives of FDI and criticised the less impact of FDI to developing countries. The advantages are more benefited the investor rather than host country. Based on this results, this study argues the important to analysis the motives of Japanese investment in Indonesia during period 2010-2016. It contributes to understand the behaviour of Japanese investor and the direction of Japanese investment in the future.

\section{Theoretical Framework: OLI Theory}

John H. Dunning released the theory of eclectic paradigm since 1958 to 2000. OLI assesses FDI relationships with multinational enterprises. According to Manuel, et al., OLI consists of three main factors: (1) ownership advantage, (2) business location, and (3) internalization advantages. This theory looks at a company's production in a country through FDI. According to Manuel (2011, p. 8) FDI has four goals:

- Resources: A country's interest in providing FDI, i.e., access to natural resources, raw materials, or other productive factors that benefit the home country

- Markets: Entering new markets and finding important new clients

- Efficiency: FDI is used to prove the efficiency of a company and make it more productive

- Strategic Assets: FDI develops competencies, resources, and capabilities that can contribute to a firm's competitive advantage

Dunning's OLI, which is explained above, shows a desire for additional resources, markets, efficiency, and industrial investment relationships as some motives of FDI. Strategic seeking will follow company strategies, thus the analysis will overlook it. 


\section{THE DYNAMICS OF JAPAN'S INVESTMENT IN INDONESIA, FROM 2010 TO 2016}

\subsection{Japanese Investment Policies and Its Implementation in Indonesia}

Japan's economic stance toward Southeast Asia, issued by Prime Minister Shinzo Abe, contains five principal issues:

- Protection and joint promotion of universal values such as freedom, democracy, and basic human rights with Association of Southeast Asian Nations (ASEAN) member countries.

- Assume that freedom and the open sea are being overseen by applicable laws and accept that the United States will balance such conditions in the region.

- $\quad$ Promote trade and investment and develop goods, capital, people, and, through economic cooperation, services.

- Protect and maintain the diversity of Asian cultures and traditions.

- Promote the younger generation to enhance mutual understanding.

Japan's strategy to promote trade, investment, and economic cooperation is noted in \#3 above. These five principles (from "Abenomics") blocked China's widening influence in Southeast Asia. Abe has prioritized Southeast Asia and has pushed many of Japan's industries to invest in Indonesia. As a result, Toyota and the Mitsubishi UFJ Financial Group have increased their respective investments in Indonesia (Tay, 2013). Five members of Abe's ministry objected to only prioritizing Southeast Asia and received positive comments. Although some portions of Abenomics failed in South Korea and China, Japan continues to have bilateral Agreements with Asian countries have been in existence since World War II. The ASEAN also benefits Japan's economy.

As a developing Southeast Asian country and a member of ASEAN, Indonesia has both long- and short-term economic plans. To catch up with developed countries, infrastructure and human resources development needs to be funded. Indonesia has become an important trading partner with several developed countries, such as Japan and China, and the Indonesian government continues to look selectively for foreign funding sources.

Foreign investment is a form of governmental long-term planning. In an international context, Veronica (2013) stated that Asia can be seen as a large chessboard for geopolitical struggles. Japan has become one of the world's major economic powers, and its actions affect the behavior of other countries. In the 1980s, Japan was the world's second-largest economy. In 2014 and 2015, Japan placed second among ASEAN countries and regions for FDI. Clearly, Japan sees the ASEAN as a crucial market. Largely because of Abenomics, Japan's 2014 FDI to ASEAN regions amounted by USD 15.705 million, rising in 2015 to USD 17.395 million. In these two years, the services sector dominated ASEAN investments. 
Table 2. The Top 10 Investors in ASEAN, 2014 and 2015

\begin{tabular}{lrrrr|}
\hline \hline Country/region & $\mathbf{2 0 1 4}$ & Country/region & $\mathbf{2 0 1 5}$ \\
\hline Intra-ASEAN & 22,134 & Intra-ASEAN & 22,149 \\
Japan & 15,705 & Japan & 17,395 \\
United States & 14,749 & United States & 12,191 \\
Luxembourg & 7,997 & China & 8,155 \\
United Kingdom & 7,583 & Netherlands & 7,907 \\
China & 6,990 & United Kingdom & 6,698 \\
Australia & 6,282 & Republic of Korea & 5,680 \\
Republic of Korea & 5,751 & Australia & 5,193 \\
France & 2,761 & Denmark & 2,693 \\
Netherlands & 2,699 & New Zealand & 2,241 \\
\hline Top 10 total & 92,651 & Top 10 total & 90,303 \\
Top 10 share of FDI & $71 \%$ & Top 10 share of FDI & $75 \%$ \\
in ASEAN & & in ASEAN & \\
\hline
\end{tabular}

source: 2016 ASEAN investment report (p. 5)

The ASEAN received Japanese investments even before the 1997 Asian crisis, With Japanese FDI shifting from Newly Industrialized Countries (NIC) regions to the ASEAN region, Southeast Asia was the first object of Japanese economic diplomacy after 1950. Japan has continuously invested in Indonesia over the past 18 years, with a dip occurring in 1997 because of the Asian crisis. Although Japan's growing investment in Indonesia is a good sign for Indonesian industries, Japan nevertheless is more interested in its own companies than helping a recipient economy. As shown in Table II., Singapore was the largest country investing in Indonesia in 2016. (Indonesia and Singapore are geographically closer than Indonesia and Japan, and Singapore is an ASEAN member).

Table 3. 2016 Foreign Investments in Indonesia, By Country

\begin{tabular}{|c|c|c|c|}
\hline No & Source Country & Investment (US\$ mill.) & Project Amount \\
\hline 1 & Singapore & $9,178.7$ & 5,874 \\
\hline 2 & Japan & $5,400.9$ & 3,302 \\
\hline 3 & China & $2,665.3$ & 1,734 \\
\hline 4 & Hong Kong & $2,248.3$ & 1,137 \\
\hline 5 & The Netherlands & $1,475.0$ & 840 \\
\hline 6 & The United States & $1,161.9$ & 540 \\
\hline 7 & The British Virgin Islands & $1,157.3$ & 1,555 \\
\hline 8 & Malaysia & $1,115.6$ & 1,652 \\
\hline 9 & South Korea & $1,065.8$ & 2,996 \\
\hline 10 & Mauritius & 576.5 & 250 \\
\hline
\end{tabular}

Sumber: Indonesia Investment Coordinating Board (BKPM)

Based on data from the Investment Coordinating Board (BKPM), Japan's FDI primarily funds the manufacturing and automotive supply chain industries, which helps maintain production and quality. It is possible that Indonesia's vendors are less competitive than Japan's. 


\subsection{Identifying the Motives of Japanese Investment to Indonesia}

Japan became an investor since 1965 with small amount. After the Meiji restoration, Japan studied internationally and subsequently. It then engaged in market liberalization after the Meiji restoration. Japan's investment interest in Indonesia at that time was based on natural resources. Japan also invested in Brunei Darussalam. From 1965 to 1998, Japan's was the second-largest investor in Indonesia, after Thailand, but investments decreased in 1998 because of the Asian crisis. After Japan's economy peaked in 1980, it continued to invest in foreign countries to meet its need for raw materials, notably mineral resources.

Since 1965, Indonesia has become Japan's largest investment in Asia. Japan's investment in foreign countries started in small amounts from 1950 until the early 1970s. Before 1970, Japan's main foreign investment sector was mining. In the late 1980s, the golden years of Japanese foreign investment, the country expanded into manufacturing (Komiya, et. al., 1991, p. 48). According to Hidriyah (2009, p. 25-30), Japan invested internationally to revive industries by importing technology and to obtain loans, and to find additional labor resources.

Beginning in 1999, Japan was overtaken by Thailand as Indonesia's largest investor. Japanese investments in Indonesia then fluctuated between 1999 and 2006. (Table 1 shows that Japanese investment in Indonesia continued to rise for the last six years). The Investment Coordinating Board stated that this relationship makes Japan an important investment partner in Indonesia. The manufacturing industry remains the largest sector for investment in Indonesia, followed by the services sector. In 2016, investments rose to USD 16.7 million, from USD 11.8 million in 2015.

Since the 1990s, Indonesia has not been an investment priority for Japanese investors. During this period, Japan focused more on the United States, China, Singapore, and Britain. In 2016, though, Japan invested in Indonesia's infrastructure development, including construction of the Patimban port, semi-fast, Jakarta-Surabaya train, and the Trans-Sumatra Toll Road section of Padang-Bukit Tinggi Pekanbaru. Japan also cooperated with airport development (Investor Daily Indonesia, 2017).

Historically, Japan has been one of Indonesia's largest foreign investors and foreign aid providers. Indonesia has invited Japan to invest through the Japan-Indonesia Economic Partnership Agreement (JIEPA), formed in July, 2008.

As for additional data, when analyzing the investor's position in the realization of foreign investment in Indonesia from 2013 to 2016, Japan is ranked second and down in 2015 alone. This position provides an opportunity for the Indonesian government to attract Japan to remain an important investor in Indonesia, especially accompanied by infrastructure development that continues to be pursued by Indonesian government. Although Indonesia's position as the recipient of investment slumped to 5th or 8th place, even under Vietnam, Indonesia still has optimism to build the investment climate.

Graphic 1. Indonesia’s Investment Realization from 2014 to 2016 with Country Rank 


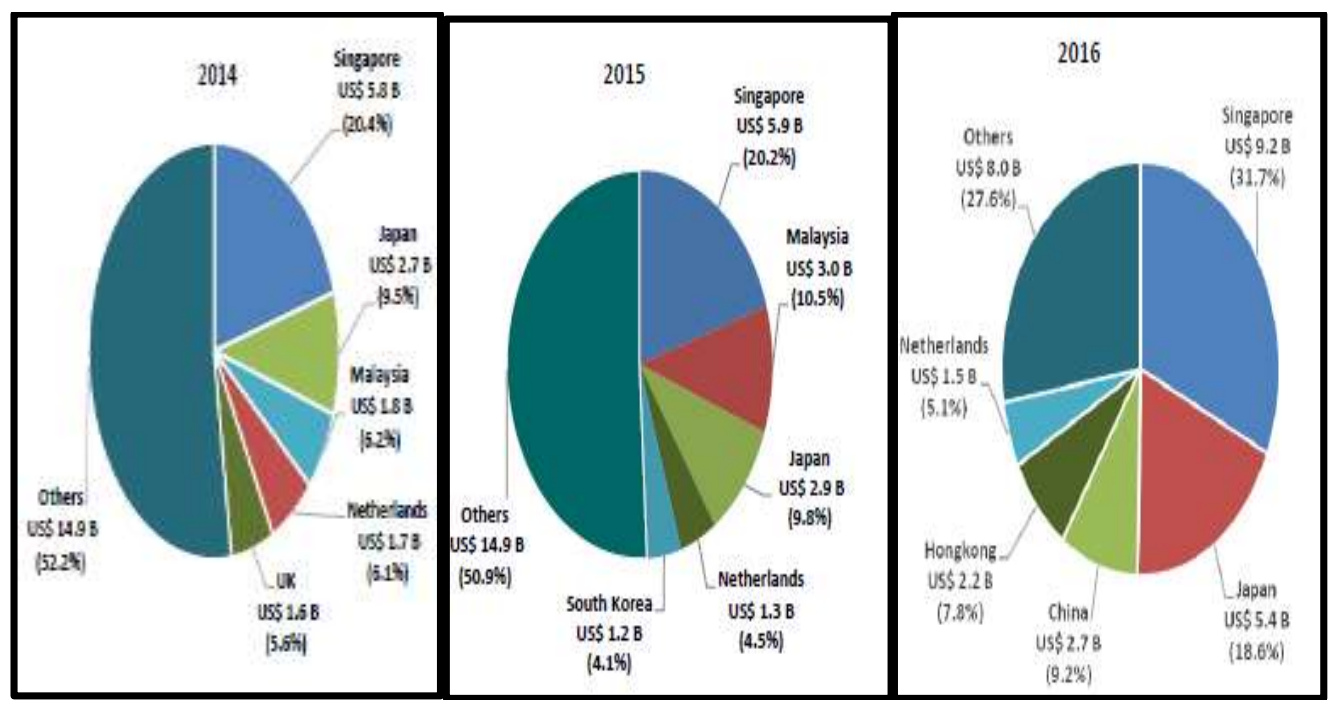

Source : Indonesia Investment Coordinating Board (BKPM Indonesia)

Between 1960 and 1980, Japan became an increasingly developed country, even reaching a trade surplus with the U.S. Andrew Beattie through Wall Street mentions two important effects of this industrial achievement: (1) The giant industry based on making business peoples' stay pleasant with large cost. In Japan, five-star restaurants and hotels are arranged as quickly as skyscrapers. (2) Businesspeople are getting tired of the joyful Japanese presence that requires them to manage the massive expenditure.

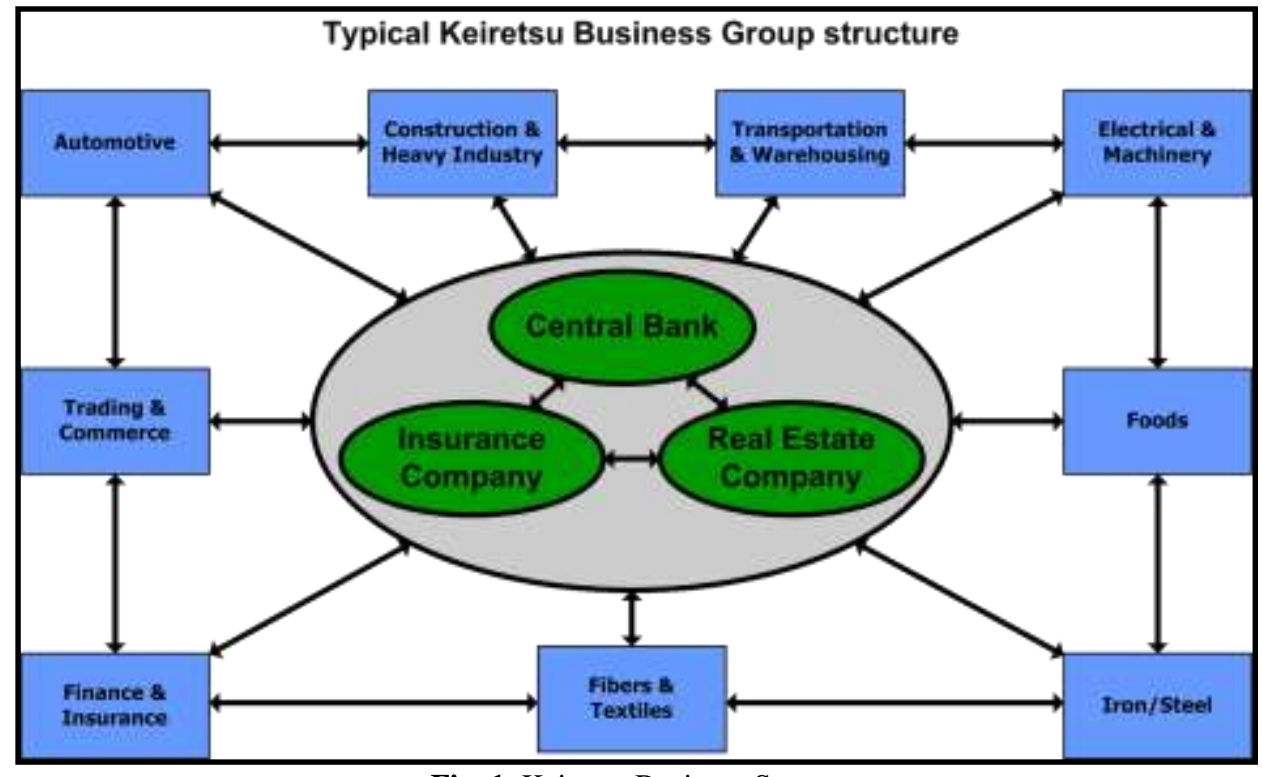

Fig. 1. Keiretsu Business Structure

Source: David Killefer. Seminar College of Management Honors, (2008, p. 9) 
While the relationship between manufacturing and consumers is similar in all countries, Japan has its own distinctive relationship. Miyashita and Russel explained that manufacturing relationships with Japanese consumers Japan are symbiotic and have a hierarchy. Further development of keiretsu affected Asian economies as well as Japan. Aoki (1995) and Fukuda (1993) both pointed out that keiretsu entered the Asian industrial market after 1980, which some experts cited as "a new economy and a political system." Keiretsu have made extensive use of FDIs since 1980 , a process that was assisted by a $40 \%$ rise of the yen against the dollar (Mike, 2001 , p. 257). Japan's industries needed a place in which to expand, and Indonesia provided one outlet. This gave Japanese companies greater market share and expanded their number of subsidiaries.

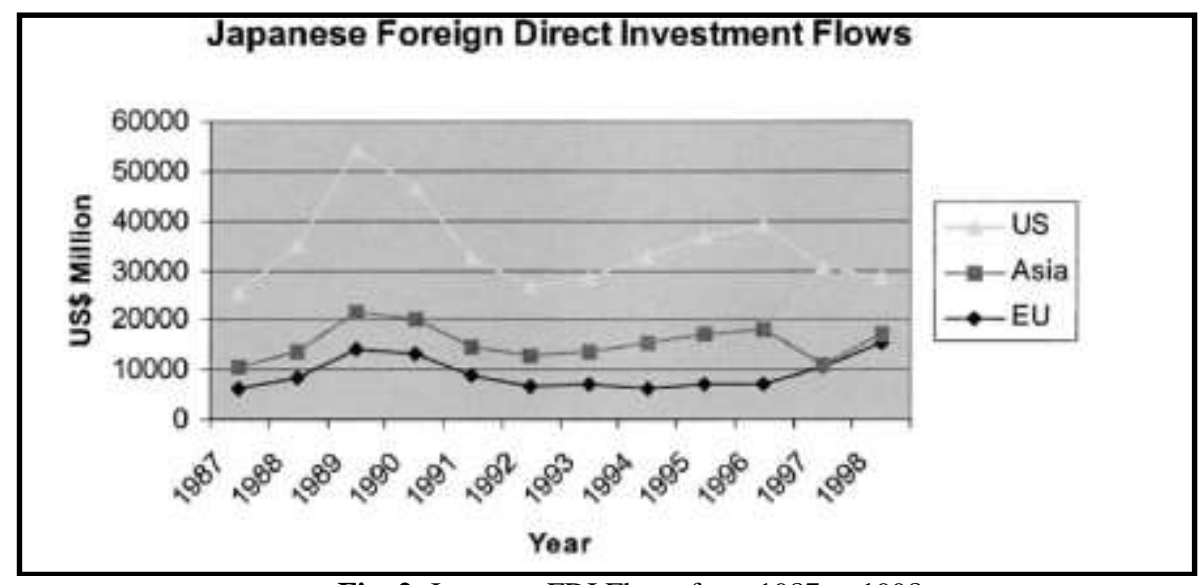

Fig. 2. Japanese FDI Flows from 1987 to 1998

Source: Mike Peng. The Keiretsu in Asia: Implications for Multilevel Theories of Competitive Advantage (2001)

In addition, Indonesia is large potential market for some products. Demand for consumer goods is rising significantly, but international trade for export-import in a bilateral context shows that manufacturing dominates. Indonesia is predicted to gain "a demographic bonus" in 2030, which should increase demand for education and food sectors. Indonesian universities often conduct education fairs for Indonesia's student to study abroad. Japanese restaurants, with Japanese menus, gain acculturation with Indonesia's tounge. Indonesia's food and beverage sectors grew in 2016. We interviewed three respondents (identified as R1, R2, and R3).

$\mathrm{R} 1$ and R2 work for the same company in the food and beverage industry, and R1 is the CEO of an established Japanese restaurant. R1 choose to invest in Indonesia because of the potential market and access to crude palm oil. R2, who choose Indonesia as an investment partner because of its manpower, saw Indonesia's middle class rising with the country's economic growth, and he recognizes the close relationship between Indonesia and Japan. R3 is the President and Director of an education company that offers Japanese language lessons and provides information to Indonesians looking to study in Japan. He saw Indonesia as a good market for education because of the "demographic bonus." His company has offices in other Southeast Asia countries, such as Vietnam, the Phillipines, and Thailand, but he is focusing on Indonesia.

All three respondents noted Indonesia's market potential, especially in the food and beverage industries. This claimed that investors will always look for market potential to invest. 
The relation between industrial sector and market seeking in other countries will always follow. The five largest industries in Indonesia are as follows:

- $\quad$ Food and Beverages: $8.46 \%$

- [Leather, Goods made from leather,] and Footwear: 8.15\%

- $\quad$ Chemicals, Pharmaceuticals, and Medicine: $5.48 \%$

- $\quad$ Non-Metal Digging Goods: $5.46 \%$

- Machinery and Equipment: $5.05 \%$

\section{CONCLUSION}

The Indonesian government anticipates continued foreign financing and hopes that these financing sources will be sufficient. The country maintains extensive natural resources, which are valuable to Japan. Historically, Japan's investments in Indonesia have fluctuated, for different reasons. Currently, Japan is the second-largest investor to ASEAN countries and to Indonesia. Based on OLI theory, two reasons to invest abroad are to extend market reach and to have access to greater resources Indonesia also offers a large base of manpower and a rising middle class. Japan's increasing investments in Indonesia from 2010 to 2016 indicates the country's continuing interest.

\section{ACKNOWLEDGEMENT}

This research based on grant scheme of PITTA (Publikasi International Terindeks untuk Tugas Akhir) or also known as Indexed International Publications for Final Projects toward Universitas Indonesia students. Thank you to Asra Virgianita as my advisor and thank you to The Directorate of Research and Community Engagement of Universitas Indonesia (DRPM UI).

\section{REFERENCES}

[1]. Secretariat, ASEAN (2016). ASEAN investment report 2016: Foreign direct investment and MSME linkages. Jakarta: ASEAN Secretariat.

[2]. Badan Koordinasi Penanaman Modal. Siaran Press Realisasi Investasi Tahun 2016 $\begin{array}{lllll}\text { Meningkat } & 12,4 \% & \text { Dibanding } & \text { Tahun } & \end{array}$ http://www2.bkpm.go.id/images/uploads/file_siaran_pers/Siaran_Pers_TW_IVNarasi_Tunggal-250117.pdf. A

[3]. Badan Koordinasi Penanaman Modal. Perkembangan Realisasi Investasi PMA Berdasarkan Laporan Kegiatan Penanaman Modal (LKPM) Menurut Sektor 2016. Accessed 3 April 2017. http://www.bkpm.go.id/en/investing-in-indonesia/statistic

[4]. Investor jepang. Investor Daily, Indonesia. Retrieved from http://id.beritasatu.com/tajuk/investor-jepang/167602

[5]. Ferreira, M. P., Pinto, C., Serra, F., \& Filipe, L. (2011). John Dunning's influence in international business/strategy research: A bibliometric study in the strategic management journal. Journal of Strategic Management Education, 7(2), 1-24.

[6]. Hidriyah, S. (2008). Fluktuasi investasi jepang di Indonesia periode 2001-2007 (Doctoral dissertation, Universitas Indonesia.) 
[7]. de Miguel, E. (2013). Japan and Southeast Asia: From the Fukuda Doctrine to Abe's five principles. UNISCI Discussion Papers, (32), 99-116.Negara, S. D., \& Adam, L. (2012). Foreign direct investment and firms' productivity level: Lesson learned from Indonesia. ASEAN Economic Bulletin, 29(2),116-127.

[8]. Nasional, B. P. P. (2016). Perkembangan Ekonomi Indonesia dan dunia. Laporan Deputi Bidang Ekonomi Kementrian PPN/Bappenas. Jakarta (ID): Bappenas.

[9]. Peng M. W., Lee, S. H., \& Tan. J. J. (2001). The keiretsu in Asia: Implications for multilevel theories of competitive advantage. Journal of International Management 7(4), 253-276.

[10]. Ramli, M. (2006). Peranan pemberian insentif PPH terhadap Investasi Asing Langsung (Foreign Direct Investment) Negara Jepang (Doctoral dissertation, Universitas Indonesia.)

[11]. Tay, S. (2013). Abenomics, Asia \& ASEAN. Dalam Japan Spotlight. Retrieved from www.siiaonline.org/wp-content/uploads/2016/10/2013-09-abenomics-asean.pdf

[12]. Veronica, N. W. (2015). Rivalitas Cina dan Jepang dalam Institusi Regional Asia Timur. Global Jurnal Politik Internasional 16(1) Departmen Ilmu Hubungan Internasional Fakultas Ilmu Sosial dan Ilmu Politik Universitas Indonesia 